\title{
Journey to the End of the Night: Disillusion and Derangement among the Senses
}

\author{
Andrew Irving \\ University of Manchester
}

\begin{abstract}
The journey returns us to shared originary meanings of experience, trial, and travel, wherein ex signifies "out of," while peira means "attempt, trial, test" and possesses the same root per as the Germanic fahr ("to travel"). The experience of traveling to an unfamiliar place often retains the character of a testing out, and exposes a flux of unfamiliar perceptions and sensations. Accordingly, this article uses Louis-Ferdinand Céline's journey from Europe to Africa to America, as recounted in his novel, Journey to the End of the Night, published in 1932, to explore some of the varying modes of corporeal experience and aesthetic appreciation that arise through travel and movement. It suggests that these constitute their own distinct types of knowledge and understanding. Inevitably, this raises important epistemological questions about how we know and understand the world, in that the initial impressions and provisional misunderstandings of transitory encounters are dismissed once the traveler, or anthropologist, gains a greater in-depth knowledge and understanding of the environment through longer-term dwelling. However, is there something to be gained: different perspectives and modes of knowing that emerge at the beginning, middle, and end of the journey?
\end{abstract}

Keywords: architecture and urban planning, Céline, New York, perception, senses 


\section{Andrew Irving}

\section{The View above Manhattan}

From up high where I was, you could shout anything you liked at them. I tried. They made me sick, the whole lot of them. I hadn't the nerve to tell them so in the daytime, to their face, but up there it was safe. "Help! Help!" I shouted, just to see if it would have any effect on them. None whatsoever. Those people were pushing life and night and day in front of them. Life hides everything from people. Their own noise prevents them from hearing anything else. They couldn't care less. The bigger and taller the city, the less they care. Take it from me. I've tried. It's a waste of time. (Céline 2004 [1932]: 180)

I , like Céline, am a European looking down on Manhattan from my apartment building, and whose perceptions of the city below are framed by having spent the previous year living in Africa. ${ }^{1}$ Manhattan's long, straight avenues, full of vast buildings and consumer goods, look strange, because my reality is formed in contrast to the sights and sounds left behind in Uganda, rather than what is empirically present and perceived. Contrariwise, the things that I experienced in Africa are retrospectively reordered in relation to my current environment, reinforcing MerleauPonty's (1968) argument that "reality" does not definitively belong to any perception insofar as it always exists "further on." William James similarly asserted that experiences emerge through a process of change that "continually gives us new material to digest" (2000: 150). For both MerleauPonty and James, truth is not inherent to or coterminous with perception or experience, but is something that is made true through subsequent events and experiences. Consequently, I cannot even trust my own account of the past year, nor completely believe the evidence of my eyes while looking at Manhattan. Instead, I am living the "experience of dis-illusion, wherein precisely we learn to know the fragility of the "real" (Merleau Ponty 1968: 40).

As I look down, I see how the reality and residue of one environment seems to merge and inhere in another, or perhaps many, in that I also see traces of Manchester in Manhattan, and constantly compare it with London. There are hundreds of people on the streets below, working, shop- 


\section{Journey to the End of the Night}

ping, socializing, walking, resting, eating, and going about their daily lives, unaware that they are being watched, or, in Céline's case, shouted at. However, the limits of human perception and understanding mean that even when mimicking the transcendental eye of God, we only see a tiny fraction of New York's reality or its population's activities. Given the size and diversity of the modern metropolis, we might wonder how a city of New York's dimensions might be explained or described? Wittgenstein asked the same question about human behavior:

How could human behaviour be described? Surely only by showing the actions of a variety of humans, as they are all mixed up together. Not what one man is doing now, but the whole hurly-burly, is the background against which we see an action, and it determines our judgement, our concepts, and our reactions. (Wittgenstein in Dreyfus 1995: 7)

Céline’s reaction to Manhattan's hurly-burly impatiently emerges out of his own mania, repulsion, and fiction. He rants about human obsession and disinterest rather than appreciating the city's culture and architecture...merely seeing the people below disrupts his moral and emotional well-being...he shouts for help...they don't respond...he is fearful...they make him feel sick. Thus, although Céline is high up, the population beneath continues to affect his corporeal being, and inform his observations and appreciation of human behavior: the experiential body, perception, and reality remain tenuously intertwined.

By contrast, when I look down on Manhattan as an anthropologist, my view is framed by the dominant disciplinary imperative to understand people's actions through the rational means and methods of social-science, rather than forming judgements based on momentary feelings and passing bodily sensations, and using fictional exaggeration as a mode of representation. There is a strategic downplaying of the variability of the researcher's bodily being, and its role in influencing perception and understanding, even though every body and situation affords a unique perspective beyond that obtained through shared phylogeny. An individual's brain and body, like the world they dwell in, are never in the same state twice but always in process: the "reality" generated via the corporeal flux and instability of the finite body is provisional, hypothetical and remains malleable, thereby raising fundamental questions about how anthropologists perceive, com- 


\section{Andrew Irving}

prehend, and make claims about the world. Fieldwork consists of thousands of different encounters and provisional realities, stretching from arrival to departure, and encompassing persons, situations and interactions that may share little other than the researcher's presence. Consequently, in order to transcend the particularity of each research encounter and formulate theory, the anthropologist must possess an almost machine-like continuity and invariability throughout time and space. How can a man be so constant? Terrifying this.

In response, this article uses Céline's journey from Europe to Africa to America, as recounted in his novel, Journey to the End of the Night, published in 1932, to explore some of the varying modes of corporeal experience and aesthetic appreciation that arise through travel and movement, and suggests these constitute their own distinct types of knowledge and understanding. Céline's perception, appreciation and representation of the world relentlessly change according to the inconsistency of his mental and bodily condition. People and places are encountered through a veil of passing moods: tiredness, illness, euphoria, lust, shame, fear, joy, late-night sentimentality, morbid obsession and the desire for revenge. Even when couched in everyday familiarity, Céline's world is inconsistent, untidy and emotionally entangled: a product of the imperfection and variability of human perception rather than systematic methods and rational theory. His journey raises many questions about the qualities of truth generated through ethnographic research and how its epistemological and ontological status is always subject to changes in body, mood, and perception. ${ }^{2}$

\section{Céline's Journey}

Céline was born in Paris in 1894, and raised as an only child. Travel began early. At thirteen, Céline's parents sent him to Germany for a year to learn German, and afterwards, to England to learn English. Conscripted by the French cavalry once he turned eighteen in 1912, Céline saw action two years later, following the outbreak of World War I. He showed great bravery and was seriously wounded while carrying dispatches under fire in Flanders in 1914. He spent the following months hospitalized, and was awarded the prestigious Médaille Militaire for his exceptional courage. Céline was discharged from the army due to his injuries, and soon left 


\section{Journey to the End of the Night}

Europe in pursuit of adventure and the futile attempt to escape the horror of his battlefield experiences. In 1916, he journeyed by boat to equatorial Africa and found work in the newly founded colony of French Cameroon, where he ran a trading post for a lumber company.

Céline returned to France after contracting malaria and dysentery, complete with a new interest in medicine after witnessing the suffering of African people. He trained to become a doctor and began working for the League of Nations, which entailed a return to Africa to practice medicine and work on public health. Eventually, he set up a general practice in the working class slums around Clichy in Paris, often treating for nothing people who other doctors would not treat because they were too poor to pay. Céline's practice was a financial shambles but this did not prevent him from publishing pamphlets about the sanitary conditions endured by poor working families, savagely criticizing the public health policies that bore little relation to the social reality that he saw each day.

In the 1930s, Céline began publishing pacifist pamphlets that were explicitly anti-Semitic, and also had his first novels published. He spent World War II working as a ship's doctor and with an ambulance. Toward the end of the war he fled France, worried that his anti-Semitic pamphlets would come back to haunt him, and holed up in a castle in southern Germany before traveling to Denmark, where he was arrested for treason and imprisoned for eleven months in 1945. From 1946, he lived in exile but was tried for collaboration in Paris in his absence. He was sentenced to a year's imprisonment and had all his property confiscated. An amnesty allowed him to return to Paris in 1951, where he lived in a run-down house surrounded by birds and feral cats, but he continued to write and practice medicine until his death in 1961.

Céline's first novel, Journey to the End of the Night, reworks his journey from Europe to Africa to America, continually exposing the dynamic relationship between travel, perception, and the body. Journey is primarily a "vocal novel" that comprises of an arduous existential and moral journey, recounted by Céline's highly unreliable narrator, a medical doctor called Bardamu. Although Bardamu and Céline travel to the same places, follow similar life trajectories, and share many experiences, they are not the same person. Instead, the journey that Bardamu undertakes in Journey is neither straightforward, nor autobiographical, but merges first-hand experiences, a displaced psyche and a restless body to produce something far stranger than fiction.

142 JOURNEYS, VOL. 9 ISSUE 2 


\section{Andrew Irving}

Bardamu, like Céline, volunteers for the war in a mad moment, and is soon exposed to the horror of bodies with their internal organs displayed: a reality that he has hitherto been unprepared for and that reveals an essential truth about human beings and their biology. Bardamu is primarily portrayed as a coward, an embellisher, and an opportunist, with an instinct for self-preservation. Yet, despite his cowardice, he ends up seriously injured, spends weeks in hospital, and is awarded the Médaille Militaire. Bardamu is more intent in exploiting the opportunities presented by sickness and hospitalization than getting better, especially as recovery carries the threat of reacquainting himself with the first-hand experience of battle and its effect on the body. It is of little surprise that combat changed the way Céline and Bardamu saw things, for, according to Martin Jay, World War I literally transformed combatants' visual perception:

The Western front's interminable trench warfare created a bewildering landscape of indistinguishable, shadowy shapes, illuminated by lightning flashes of blinding intensity, and then obscured by phantasmagoric, often gas-induced haze. The effect was even more visually disorienting than those produced by such nineteenth-century technical innovations as the railroad, the camera or the cinema. When all that the soldier could see was the sky above and the mud below, the traditional reliance on visual evidence for survival could no longer be easily maintained. ... Escape was provided by focussing on the one thing that remained visible from the trenches, at least when the gas or smoke was not interfering: the boundless sky, whose dreamy beauty could be ironically juxtaposed to the brutal reality of earthly combat. (1991: 15-16)

After his wartime experiences, injuries and convalescence, Bardamu is told to beat it from the army and becomes intent on leaving old Europe behind. "To Africa," he declares, "the further the better" (Céline 2004:104), and boards a boat for the tropics. Already attuned to the potential disintegration of every human body through his wartime experiences, Bardamu witnesses extraordinary changes in his fellow passengers as the boat nears the equator and their European bodies disintegrate in the heat to reveal persons stripped of social manners and bearing. In the process, something more essential and biological comes out of the human form: 


\section{Journey to the End of the Night}

It didn't take long. In that despondent changeless heat the entire human content of the ship congealed into drunkenness. People moved flabbily about like squid in a tank of tepid smelly water. From that moment on we saw, rising to the surface, the terrifying nature of white men, exasperated, freed from constraint, absolutely unbuttoned, their true nature, same as in war. That tropical steam bath called forth instincts as August breeds toads and snakes on the fissured walls of prisons. In the European cold, under grey, puritanical northern skies, we seldom get to see our brothers' festering cruelty except in times of carnage, but when roused by the foul fevers of the tropics, their rottenness rises to the surface. That's when their frantic unbuttoning sets in, when filth triumphs and covers us entirely. It's a biological confession. (2004: 106)

The "biological confession" elicited by the tropical heat is an existential disclosure about how different bodily surroundings alter people's perceptions, morals and actions. Heat and cold have different effects but it is the transition between the two that is necessary to open up the body's essential flux and instability. For despite appearances, we humans are mostly liquids in our constitution, and Céline exposes the fundamental ontology of human bodies: their form is somewhere between a liquid and solid, as are their morals and judgements.

To obtain this truth, Bardamu must journey beyond Europe, for truth is not easily obtained by rational deduction or resting in a cold place but requires different conditions of culture, climate and environment. Ideally, the journey should involve extreme social discomfort and physical restlessness to properly loosen the metaphysics and cultural presuppositions of habit, conditioning and practice. The arduousness and displacement of Bardamu's journey reworks naturalized perceptions and practices, until the incongruity and contingency of all actions and practices are exposed. Upon arrival, his customary bodily comportment is already "made-strange," in the same way that words are transformed when removed from habitual, everyday speech and relocated in poetry. Once relocated on African soil, a European cannot escape the bodily consequences and exaggerated environmental determinism of a "life spent waiting for the thermometer to go down" (2004: 117) anymore than in Europe's puritanical cold. The overbearing equatorial heat emphasizes the corporeal strangeness, insofar as even the healthiest persons undergo the existential journey from health to illness. 


\section{Andrew Irving}

In the climate of the Fort-Gono the European cadres melted faster than butter. A battalion was like a lump of sugar in your coffee; the longer you looked the less you saw. Most of the white conscripts were permanently in the hospital, sleeping off their malaria, riddled with parasites made to order for every nook and cranny in the body, whole squads stretched out flat between cigarettes and flies, masturbating under mouldy sheets, spinning endless yarns between fits of painstakingly provoked and coddled fever. ... In the apathy of those long malarial siestas, the heat is such that even flies rest. From bloodless, hairy arms on both sides of the beds dangle grimy novels, all in tatters. (2004: 135)

By stressing the body's liquidity, Céline exposes the physical and moral infirmity of a body that can melt (Sturrock 1990). It requires an enormous effort and will to simply stand upright, in all its moral and human connotations (which were richly explored by Freud [2004] and Erwin Straus [1966]).

The value placed on the perpendicular diurnal body is equally apparent among the expatriate administrators of Conrad's Heart of Darkness, who become sick and lost to the jungle within weeks of arrival. The single exception is the colonial officer who keeps his position because he never gets ill, and, accordingly is perhaps not completely human. Instead, he is kept upright and healthy through the excess starch in his shirt that prevents his body from collapsing like the others (Clifford 1997). However, whereas Conrad offers a realistic portrayal of equatorial life through details only accessible through his first-hand travels and travails, Céline's method is exaggeration, as suggested in John Sturrock's brilliant analysis of Céline's work:

The West Africa of the Journey is a site of disease and bodily degradation far worse than any reality, for in describing it Céline has literally turned up the heat, so that previously solid human organisms are threatened constantly by an equatorial melt-down. (1990: 13)

This does not mean that Céline's account is false, for, as John Berger observes, no story is a straightforward recollection or mirroring of "real" events, as perceived and experienced at the time. Instead, a story offers a "living portrait" that is continually reworked and recast (Berger 1979:9; in Jackson 2002). 


\section{Journey to the End of the Night}

All forms of representation, verbal or visual, involve process and variation, as tellingly illustrated by Merleau Ponty's analysis of Cezanne's painting. It would take Cezanne 150 sittings to paint a single portrait: what others would call a work was for Cezanne merely "an attempt, an approach," wherein "nine days out of ten all he saw around him was the wretchedness of his empirical life and of his unsuccessful attempts, the debris of an unknown celebration” (Merleau Ponty 1998: 75). Whether in speech or painting, impressionism, exaggeration, embellishment, caricature and irony are all ways of capturing truths that seem to exist beyond what is empirically seen or said. They do not negate realism but suggest a supplementary, more liquid and sensuous reality: a reality that is found in carnivalesque imagery:

Because of their obvious sensuous character and their strong element of play, carnival images closely resemble certain artistic forms, namely the spectacle. In the basic carnival nucleus of this culture is by no means a purely artistic form nor a spectacle and does not, generally speaking, belong to the sphere of art. It belongs to the borderline between art and life. In reality, it is life itself, but shaped according to a certain pattern of play. (Bakhtin 1984: 7)

Bardamu's "truths" emerge and are animated through the exaggerated experiences of the liquid, living body, as it undergoes the transforming effects of the journey. The focus on exaggeration and bodily instability is not brought to an end when Bardamu leaves Africa for New York, but enters new social and climatic conditions. The modernity of New York is healthier than Africa, but no less primitive or extraordinary. However, given that Bardamu is a bodily native of Europe, New York would not have seemed as extraordinary had he arrived direct from Paris. So, to better understand the qualities of Western modernity, it is necessary for Bardamu to leave its confines and journey far away - a view from afar, in Levi-Strauss's terms - in order to experience it more fully on his return. Again, there is an arduous boat journey; only this time Bardamu is among black Africans who have turned the tables and sold him into slavery. When Bardamu finally arrives in New York, the city's height, scale, and electricity would have been extraordinary coming straight from Europe, let alone after months in Africa. The city cannot help but impress itself on 


\section{Andrew Irving}

Bardamu's sense organs, which are realigned in relation to the new environment. While Africa is frequently described through its smells, New York is mostly portrayed through its dizzying height and industrial-level noise, thereby indicating Western modernism's privileging of the eye and ear over the nose (Sturrock 1990).

Bardamu describes for the reader how the world's most modern city is experienced when arriving straight from Africa: it contains golden districts, lights that shine like jewels, faces of every shape and description, and a rich tapestry of persons that contains the entire cross-section of humanity, not just the poor. However, like most cities, New York initially exists as a space in Bardamu's imagination, conjured up by his lustful leanings toward Lola, the American nurse who treated his wounds in hospital, and, thereafter becomes the object of Bardamu's unceasing attention, fueling his fantasies about America:

To me her body was a joy without end. I never wearied of exploring that American body. I have to admit I am a terrible lecher. I still am. And I formed the pleasant and fortifying conviction that a country capable of producing bodies so daringly graceful. So tempting in their spiritual flights, must have countless other vital revelations to offer, of a biological nature, it goes without saying. I made up my mind while feeling and fondling Lola, that sooner or later I'd take a trip, or call it a pilgrimage, to the United States, and the sooner the better. (2004: 54)

Thus, it is against such imagery that reality is measured on arrival, and when Bardamu first sees the city he is immediately impressed:

Talk of surprises! What we suddenly discovered through the fog was so amazing that at first we refused to believe it, but then, when we were face to face with it, galley slaves or not, we couldn't help laughing seeing it right there in front of us. Just imagine, that city was standing absolutely erect. New York was a standing city. Of course we'd seen cities, fine ones too, and magnificent seaports. But in our part of the world cities lie along the seacoast or on rivers, they recline on the landscape, awaiting the traveller, while this American city had nothing languid about her, she stood there as stiff as a board, not seductive at all, terrifyingly stiff. (2004: 169) 


\section{Journey to the End of the Night}

After Bardamu's diseased adventures in Africa, New York is life affirming:

That was America! I had arrived! It's a pleasure to see that sort of thing after so many parched adventures. It's as life giving as fruit. (Céline 2004: 172)

Ever the opportunist, the people, but especially the women, are as impressive as the height of the buildings:

There erupted a sudden avalanche of absolutely and undeniably beautiful women. What a discovery! What an America! What ecstasy! ... Every conceivable promise of face and figure fulfilled! Those blondes! Those brunettes! Those Titian redheads! And more and more kept coming! Maybe, I thought, this is Greece starting all over again. Looks like I just got here in time. (2004: 177)

\section{Sins of Rationality}

When Bardamu arrived in Manhattan he encountered an island approximately 12.5 miles long and 2.5 miles across, covering only 22.2 square miles of New York City's' 469 square miles. ${ }^{3}$ The city was founded in 1626 , with construction beginning at Manhattan's southern tip, and, thereafter, expanding northwards (Mackay 1987). By 1653, the city had only reached modern-day Wall Street, which marked the city's northernmost extension. Even by the 1800 census, the population was a mere 60,489, and building had only just reached the modern-day city hall. Chelsea and Greenwich were outlying villages; Midtown was farmland; and large parts of the island were covered in thick woods with many roads meandering in accordance with the population's agricultural needs.

Disease was rife in Manhattan, just as in Céline's Africa. Likewise, one of the main culprits was yellow fever caused by mosquitoes thriving in Manhattan's summer climate, swamps and stagnant pools. Its symptoms included fever, skin eruptions, nausea, black vomit, incontinence, jaundice and eventually death. After the terrible epidemics of 1794, 1795, 1798, and 1805 (Burrows and Wallace 2001), it was clear that something had to 


\section{Andrew Irving}

be done. Would it be possible, the city's councillors and state legislatures wondered, to build health and well-being into the city by altering its topography? It was not known to medical science that yellow fever was caused by mosquito bites, and it was, instead, linked to odors, filth, and people. Accordingly, the idea at stake was whether a more orderly and controlled city could prevent disease and epidemic as people expanded inexorably northward. The population expanded from the 33,111 sometimes-feverish souls in the first census of 1790 to 96,373 in 1810 . With a further, massive, tenfold population increase anticipated, the city councillors decided to "unite regularity and order with the Public convenience and benefit, and in particular to promote the health of the city," in a way that would contribute to the "free and abundant circulation of air," and help regulate odors and people. ${ }^{4}$ Three men, Gouverneur Morris, Simeon De Witt and John Rutherford, were put forward "as fit and proper persons to be appointed Commissioners of Streets and Roads ... with full powers to establish a binding plan for future streets and open spaces” (Morris et al. 1811).

Céline wrote extensively on public health in his medical career and remained concerned with the affects of slums and buildings on people's health. His trip to America was, in part, to learn about and facilitate discussions on public health and, although he may not have known about the commission's intention to build health into city planning and architecture, he certainly encountered the material consequences of their actions in the commission's first important act, which was to draft a plan for the future layout of the city. In 1807 they engaged a surveyor, John Randel to survey the entire island, with the purpose of transforming its woods, swamps and grasslands into a place "composed principally of the habitations of men, and that straight-sided and right-angled houses" (Morris et al. 1811). Randel spent the next three years painstakingly measuring and mapping Manhattan's entire topography, with a resulting 7 feet 8 inch-by- 2 feet 1 inch (2.34 meters-by-65 centimeters) map, which offered unprecedented levels of detail about the island.

Randel's map is interesting, because it does not simply map Manhattan's topography, streets, and buildings of the time, but also imposes a design for the island's future, in that a grid-system is laid over the land, determining where future streets would be built. The map proposes that all roads should be straight and sequentially numbered rather than named. Streets ran horizontally across the island and were numbered 1 to 155 , 


\section{Journey to the End of the Night}

while avenues ran vertically and were numbered 1 to 12 , with an additional A, B, C, and D covering the swell of land on the Lower East Side. It was decided that no consideration was to be given to natural variations in the land, existing roads or property divisions (Mackay 1987). The map's official ratification in 1811 marks the point at which the city council confirmed that they would try to build reason, rationality and health into the city's physical layout. Moreover, the repercussions of 1811 remain visible today in the change of landscape north of Canal Street, where virtually every street and avenue follows a straight line. ${ }^{5}$

When Céline arrived in Manhattan in the 1920s, the anticipated tenfold population increase was dwarfed by the actual figures, which showed that the population had grown from 96,373 persons on the island at the time of Randel's map to 2,284,103 in the 1920 census. Thus, by the 1920s, a new sense of scale and structure had emerged against which an individual born when farmland covered most of Manhattan could compare their agricultural practices and muddy, organic desires, especially after the invention of pressured water pipes and the elevator allowed for taller and taller buildings. It is telling, therefore, that Norman O. Brown suggested that "through the city the sins of the fathers are visited upon the children" (1970: 283), for the commissioners' extended, straight avenues have long imposed their will-to-rationality upon all subsequent generations.

Consequently, although the iron, brick, concrete, steel, and glass materials of Manhattan's contemporary buildings betray the aesthetic yearnings that defined different eras they are all laid out upon the logical principles of the grid system of 1811. It is a rationality that is enforced many times a day through the ongoing encounter with the perspectival horizons formed by the city's buildings, which offer a series of extended straight edges that enables citizens to look far into the distance, much like a Euclidean drawing or one of Canaletto's paintings. A frame of receding perspectives and diminishing angles continually guides the eye toward a vanishing point on the horizon: a point distant in time and space, but "mathematically known in advance" through the type of Western scientific reason that is embedded in perspectival images and painting (Heidegger 1977; Pinney 1995). How curious, then, that Céline, whose work, Kristeva (1984) argues, offers a clear disjuncture with Enlightenment values, should be drawn to a city where streets and movement were organized along a rational grid, numbers and straight lines.

150 JOURNEYS, VOL. 9 ISSUE 2 


\section{Andrew Irving}

We might argue that people's movements within New York are not just framed by rational topography but also the pursuit and accumulation of money, insofar as the grid-like layout of the city is analogous to the grid of capitalism: with short-term paths (streets), long-term futures (avenues) and a retirement pension mathematically known in advance on the far horizon. As Whyte (1980), who walked around the city for sixteen years as part of his revolutionary "Street Life Project," and De Certeau (1984) both observed, walking in New York is a practice whereby the ongoing tension between individual agency, architecture and wider social and economic forces is played out. It is something that tires and overwhelms Bardamu whenever he leaves his room:

Leaving the delirious gloom of my hotel, I attempted a few excursions in the main streets around about, an insipid carnival of dizzy buildings. My weariness increased at the sight of those endless house fronts, that turgid monotony of pavements, of windows upon windows, of business and more business, that chancre of the world, bursting with pustulent advertisements. False promises. Drivelling lies. (2004: 186)

Indeed, walking along the commerce-lined streets often brings about contradictory feelings, whereby rational accumulation and control are set against bodily gratification, abandon, and the capacity for resistance. For Bardamu, the paradox is exemplified by the relentlessly loose bowels in the communal toilets underneath the streets and the tight-assed restraint above on the street's surface. Moreover, the effect is especially dramatic, as it is his first experience of America:

To a foreigner the contrast was disconcerting. Such free-and-easy intimacy, such extraordinary intestinal familiarity, and up on the street such perfect restraint. It left me stunned. (2004: 180)

By now it is plain that Bardamu is becoming increasingly disenchanted with America, and in the twenty or so pages immediately after landing in New York, it is possible to trace the trajectory of his body and perception, as the initial romance and excitement of arrival eventually turn to disgust and despair. Bardamu finds himself trapped between different modalities of experience, which register at the level of his disintegrating confidence: a body without a secure place to dwell, caught in a corridor: 


\section{Journey to the End of the Night}

Struggling to walk faster in those corridors, I lost what little self-assurance I had left when I escaped from my quarantine. I was falling apart, just as I had seen my shack fall apart in the African wind and the floods of warm water. Here I was attacked by torrent of unfamiliar sensations. There's a moment between two brands of humanity when you find yourself thrashing around in a vacuum. (2004: 181)

It is instructive therefore that the original meanings of experience, trial, and travel are intimately intertwined, wherein ex signifies "out of," while peira means "attempt, trial, test," and shares the same root, per, as the Germanic fahr ("to travel") (Jackson 1996: 28). The experience of traveling to an unfamiliar place with all of its new habits and surfaces, retains the character of a testing out, which often exposes and exaggerates the contingency and fluidity of perception, as one undergoes the unfamiliar sensations and successive experiences associated with arrival, dwelling, departure and return. Arrival is framed by a series of initial sensory impressions, moral judgments and cultural (mis)understandings, whereby an unfamiliar topography merges with emotions such as romance, enchantment, displacement, trepidation, fear and excitement. Differences in language, climate, and a lack of familiar reference points combine to produce uncharacteristic sensations, the description and strangeness of which has long been the staple opening gambit of travelogue and ethnography. It remains a staple precisely because the disorientating effect of travel retains its power in a media and internet age. Even a city as recognizable as New York, known through a thousand movies, is rendered strange once the new arrival experiences the entire range of senses and enters the incomprehensible transport system. Once in Manhattan, the informal rules governing movement, behavior and spatial practice in crowded streets, subways, and shops are met by the outsider's socially uncoordinated responses: their walking-body, often hesitant and lacking habitual proprioception, stands out from other pedestrians. At mid-day, 1.2 million people, a population greater than some nations, cram into a square mile of midtown Manhattan. Moreover, the pace set by walkers is rapid, averaging up to 300 feet per minute along 22.5 feet-wide sidewalks:

They are skillful too, using hand signals, feints and sidesteps to clear the track ahead. They are natural jaywalkers, streaking across the diagonal 


\section{Andrew Irving}

while tourists wait docilely for the light. It is the tourists, moreover, who are vexing, with their ambiguous moves and maddeningly slow gait. They put New Yorkers off their game (Whyte 1992: xxxi).

Locals experience and negotiate the city's complexity through familiar paths, movements, and practices. So, rather than always being consciously aware of their actions, they exist in the realm of what Merleau-Ponty describes as the "I can" of the coordinated and habitual body, which precedes and sets the conditions of possibility for the "I know" of the cogito (Whyte 1992: 137). In other words, local subjects are involved in a practical, non-representational relationship with their environment; in which many actions, including glancing, looking, walking, and spatial etiquette, form a repertoire of embodied practices enacted each day. Such knowledge does not take the form of conscious rules, cognitive maps, and mental representations of knowledge about New York. Instead, it is that knowledge, as embedded within nerve and muscle, and synchronised with the rhythms of the city.

Because new arrivals must frequently enter the self-conscious and reflective realm of the cogito to know how to act or where to go, they potentially see, sense, and understand things that the local does not. Habit and embodiment involve a repetitive conditioning of sensory stimuli, whereby the nervous system becomes accustomed to many phenomena. Consequently, although the physical organism registers the surrounding sights and sounds, they do not become part of conscious awareness. Indeed, in Metropolis and Mental Life (1950 [1903]), Simmel memorably draws attention to how simply being in a city means having one's nervous system shaped by an intensity of stimulation which finds its realization in the blasé mindset that protects city dwellers from overstimulation. ${ }^{6}$ There is simply too much "reality" to take in, and Simmel suggests that the counterintuitive notion that consciousness, rather than giving access to the world, acts as a buffer through the patterning, familiarization, and arrangement of sensory experience. Furthermore, although we cannot ascertain the particular content of the consciousness of arrivals and locals walking around New York (or assign them a shared metropolitan subjectivity as Simmel did), we can nevertheless highlight how different qualities of lived experience emerge in relation to the familiarity or otherwise of the environment. 


\section{Journey to the End of the Night}

Most obviously, the new arrival's nervous system is immersed in a vast array of previously unexperienced sights, sounds and smells. No longer surrounded by familiar buildings, each street is an aesthetic and sensory discovery, rather than a familiar route. Disorientation and displacement affect the habitual "from-to orientation" of the human body, which structures the relationship of a body with its surroundings (see Leder 1990), transforming embodied rhythms and dispositions to make possible insights that might otherwise remain unknown. The arrival's attention is constantly drawn to actions, behaviors and architectural features that may escape the local, and elicit new connections between a city and its people. However, the sensory impressions of the initial encounter soon give way to reveal another mode of perception: buildings are recognized; places are revisited; streets are rewalked; and the city takes a different shape. Such acts of recognition produce their own affects and are variously interpreted, as Freud experienced when walking around an unknown town, re-encountering the same red-light district for a third time, and likening it to the sense of helplessness experienced in some dream-states:

As I was walking, one hot summer afternoon, through the deserted streets of a provincial town in Italy which was unknown to me, I found myself in a quarter of whose character I could not long remain in doubt. Nothing but painted women were to be seen at the windows of the small houses, and I hastened to leave the narrow street at the next turning. But after having wandered about for a time without enquiring my way, I suddenly found myself back in the same street, where my presence was now beginning to excite attention. I hurried away once more, only to arrive by another detour at the same place yet a third time. Now, however, a feeling overcame me which I can only describe as uncanny, and I was glad enough to find myself back at the piazza I had left a short while before, without any further voyages of discovery. (Freud 1955: 237)

As places become more familiar, the body tends to recede from consciousness as the person becomes accustomed to its social rhythms, cultural life and practical activity. New forms of "understanding” become incorporated within a person's nerves and muscles, as they begin the process of acquiring a "body which "understands"” (Merleau-Ponty 1992: 144). This implies that traveling to new surroundings does not simply 


\section{Andrew Irving}

entail a change in environment but also the body insofar as both the external reality and perceiving organ are transformed, frequently existing in a heightened dialogic and transitional state before settling into more familiar patterns of embodied activity. Over time, the provisional realities and hypotheses of the initial stages, when many things are newly encountered, are replaced and surpassed, and the world is re-interpreted: another realm of knowledge is entered.

\section{Lies and Last Words}

The correlation between travel, anthropology and other cultural encounters, including travel writing, missionary activity and exile, is well documented. What potentially distinguishes anthropological knowledge is not so much the embodied understanding that emerges through the extended engagement with place but the explicit focus on social interaction and the use of systematic methods and ethnographic theory. Typically, initial theories, impressions and understandings are dismissed as the anthropologist obtains greater knowledge and familiarity. However, given the multiple perspectives generated through different stages of the anthropological journey, we need to ask what might be gained by embracing the flux, contingency and instability of perception, or taking seriously the ephemeral insights and passing knowledge of the successive modes, especially the initial encounter? Can these be ascribed an equal, but different status to other forms of knowing? If not, on what epistemological grounds should we distinguish the different perspectives and modes of knowing that emerge at the beginning, middle and end of fieldwork, or afterwards while writing up? ${ }^{7}$

Bardamu's journey from Europe to Africa to New York can be read as a living testament to Rimbaud's call for a derangement of the senses, in which the inconsistency of a living body (leiber) generates multiple and sometimes contradictory truths from moment to moment. In Bardamu, we meet a man unwilling to theorize much beyond his current mood and bodily condition, and whose movement is continually constrained by architecture:

Maybe those vast accretions of matter, those commercial honeycombs, those endless figments of brick and steel didn't affect the habitués the 


\section{Journey to the End of the Night}

way they did me. To them perhaps that suspended deluge meant security, while to me it was simply an abominable system of constraints, of corridors, locks and wickets, a vast, inexpiable architectural crime. Philosophizing is simply one way of being afraid, a cowardly pretence that doesn't get you anywhere (2004: 187)

Philosophizing gets Bardamu nowhere, because he favors, and sees as more authentic, the empirical knowledge gained by the moving body coming up against inhuman obstacles, rather than that obtained by the application of abstract reasoning. Minds that travel without their bodies was the preserve of Victorian armchair anthropologists, and it is still the preferred method of some contemporary cultural commentators, who decline to venture to the places and cultures that they purport to explain. Here, the historical epistemological distinction between rational and empirical modes of inquiry contrasts the mind's ability to transcend its immediate surroundings and obtain knowledge beyond its location in time and space, with that of the proximate and provisional knowledge of the finite, corporeal body. However Bardamu constantly refuses the possibility of isolating and treating as distinct the former, without dragging the body along and literally incorporating the latter's variability and instability. While he also mistrusts the provisional, mortal and disorientated understandings obtained by traveling to a foreign country, he prefers this to divine transcendence as a way of obtaining truth. Tellingly, in between the romance of Bardamu's initial encounter with New York, and his subsequent stupefaction and disenchantment, he says that he learns to see the world "as it really is":

That's what exile, a foreign country is, inexorable perception of existence as it really is, during those long lucid hours, exceptional in the flux of human time, when the ways of the old country abandon you, but the new ways haven't sufficiently stupefied you yet (2004: 194)

Bardumu is aware that this all-too-brief moment does not reveal an eternal truth, but one that is subject to revision by successive modes of being. Merleau-Ponty similarly cautions us by insisting that the process of disillusion is always ongoing: 


\section{Andrew Irving}

The destruction of the first appearance does not authorise me to define henceforth the 'real' as a simple probable, since they are only another name for the new apparition, which must therefore figure in our analysis of the dis-illusion. The dis-illusion is the loss of one evidence only because it is the acquisition of another evidence (Merleau-Ponty 1968: 40; emphasis in original)

The fluidity of perception apparent throughout Céline’s Journey raises important epistemological questions for social scientific disciplines, which combine first-hand empirical observation and rational theory, insofar as both the external reality and perceiving body are in constant transition:

There was also the change in habits; once again I was having to learn new ways of talking and lying. ... The new farce you're having to play crushes you with its banality, and all in all it takes more cowardice than courage to start all over again (2004: 194)

In trying to find new ways of talking and lying, possibly Bardamu is not lying to us after all or, if he is, Michael Jackson observes that a lie is not necessarily to utter something that is not true, but is often to say "what is more than true" (2002:28). Perhaps it is best to leave the last words to Bardamu:

Everything adds to your loathsome distress, forcing you in your weakened state to see things, people and the future as they are, that is, as skeletons, as nothings, which you will nevertheless have to love, cherish, and defend as if they existed. A different country, different people carrying on rather strangely... (2004: 194) 
Journey to the End of the Night

\section{Notes}

1. Céline had been working for the League of Nations in west Africa, while I spent a year doing research in Kampala, Uganda. By coincidence, the East 14th Street apartment building that I was looking down from can be seen on the second page of David Harvey's Condition of Postmodernity, in order to demonstrate the architectural realization of the utilitarian aesthetics and ideologies of Le Corbusier's modernity. It seems as if it has never been so easy to be caught between eras.

2. Obviously, this interaction also extends beyond the field, in that when we read the resulting theories and ethnographic texts, we do so in different moods and modes that influence how they speak to us or otherwise.

3. Works Progress Administration figures, 1992. Subsequent land reclamation means this figure has increased slightly.

4. All quotes concerning these council proceedings are taken from Cornell University's web archive http://www.library.cornell.edu/Reps/DOCS/nyc1811.htm

5. Randel's map can be seen online by going to the New York Public Library Digital Archive. Go to http://digitalgallery.nypl.org/nypldigital/index.cfm, and type in the map's digital identification code (54929) into the search box. Two notable exceptions to the grid system are Greenwich Village (which is subject to a preservation order) and Broadway, which, according to popular legend, follows an old American Indian track, and cuts a noticeably maverick path across the rational grid. Of course, the attempt to build rationality into a city was not new, and stretches at least as far back as Ancient Athens (see Sennett 1994).

6. A theme developed, via Walter Benjamin, in Susan Buck-Morss's analysis (1992)of aesthetics, anaesthetics, and modernity.

7. Likewise, if the iconic "year in the field" is more a reflection of the institutional constraints and demands of the $\mathrm{PhD}$ program than concerns about the quality, veracity and status of knowledge, then what forms of understanding would emerge by staying an extra three months or years?

\section{References}

Bakhtin, Mikhail. 1984 Rabelais and His World. Bloomington and Indianapolis: Indiana University Press.

Brown, Norman. O. 1970 Life Against Death. London. Sphere Books.

Burrows, Edwin, and Mike Wallace. 2001. Gotham: A History of New York City to 1898. New York: Oxford University Press. 


\section{Andrew Irving}

Buck-Morss, Susan. 1992. "Aesthetics and Anaesthetics.” in October Fall 1992 1-41

Céline, Louis-Ferdinand. (2004 [1932]). Journey to the End of the Night. Trans. Ralph Manheim. London: John Calder.

Clifford, James. 1997. Anthropology and/as travel. Paper presented to SOAS Anthropology Seminar.

De Certeau, Michel. 1984. The Practice of Everyday Life. Berkeley: University of California Press.

Dreyfus, Hubert. 1995. Being-in-the-World: A Commentary on Heidegger's Being and Time, Division 1. Cambridge: MIT Press.

Freud, Sigmund. 1955. The Standard Edition of the Complete Psychological Works of Sigmund Freud: Volume XVII. ed. J. Strachey. New York and London: WW Norton.

2004. Civilisation and its Discontents. London: Penguin.

Jackson, Michael. 1996. Things as They Are: New Directions in Phenomenological Anthropology. Bloomington and Indianapolis: : University of Indiana Press. 2002. The Politics of Storytelling: Violence, Transgression, and Intersubjectivity. Copenhagen: Museum Tusculanum Press.

James, William. 2000. Pragmatism and Other Essays. London: Penguin. Jay, Martin. 1991 “The Disenchantment of the Eye” in Visual Anthropology Review 7, no. 1.

Kristeva, Julia. 1984. Powers of Horror: An Essay on Abjection. New York: Columbia University Press.

Harvey, David. 1989. The Condition of Postmodernity. An Enquiry into the Origins of Cultural Change. Oxford: Blackwell.

Heidegger, Martin. 1977. The Question Concerning Technology. Trans W. Lovitt, New York: Harper and Row.

Leder, Drew. 1990. The Absent Body. Chicago: University of Chicago Press.

Mackay, Donald A. 1987. The Building of Manhattan. New York: Harper and Row.

Merleau-Ponty, Maurice. 1968. The Visible and the Invisible. Evanston, IL: Northwestern University Press. 1992. The Phenomenology of Perception. London: Routledge. 1994 The Merleau-Ponty Aesthetics Reader: Philosophy and

Painting. Evanston, IL: Northwestern Press 


\section{Journey to the End of the Night}

Morris, Gouverneur, De Witt, Simeon and Rutherford, John. 1811.

Remarks of the Commisioners for laying out streets and roads in the city of New York.

http://www.library.cornell.edu/Reps/DOCS/nyc1811.htm

Pinney, Christopher. 1995. "Moral Topophilia.” in Anthropology of

Landscape. eds. E. Hirsch and M. O’Hanlon. Oxford: Clarendon.

Sennett, Richard. 1994. Flesh and Stone: The body and the city in western civilisation. London: Faber and Faber

Simmel, Georg. 1950. The Sociology of Georg Simmel. Trans. Kurt H. Wolff. New York: The Free Press.

Straus, Erwin. 1966. Phenomenological Psychology: Selected papers. New York: Basic Books.

Sturrock, John. 1990. Louis-Ferdinand Céline: Journey to the End of the Night Cambridge: Cambridge University Press.

Whyte, William.H. 1980. The Social Life of Small Urban Spaces. New York: Project for Public Spaces, Inc. . 1992. "Introduction." Works Progress Administration Guide to New York City. New York: New York Press. 